\title{
KOMPOSISI JENIS DAN UKURAN IKAN YANG DITANGKAP PADA RUMPON DENGAN PANCING ULUR DI SELAT MAKASSAR
}

Species Composition and Size of Fish Caught in FADs using Hand-line in Makassar Strait

\author{
Oleh: \\ Wayan Kantun ${ }^{1 *}$, Lukman Darris ${ }^{2}$, Wayan Suma Arsana ${ }^{3}$ \\ 1 Sekolah Tinggi Teknologi Kelautan Balik Diwa Makassar Sulawesi Selatan.aryakantun@yahoo.co.id \\ 2 Universitas Cokroaminto Makassar.daris.lukman70@gmail.com \\ 3 Universitas Tomakaka Mamuju Sulawesi Barat.arsanawayan247@gmail.com \\ *Korespondensi: aryakantun@yahoo.co.id
}

Diterima: 22 September 2017; Disetujui: 3 Oktober 2018

\begin{abstract}
The objective of the researcah is to analyze the species composition and size of fish caught at shallow and deep FAD at Makassar strait. In obtaining the data, the research is using survei method carried out for four months, starting April to July 2016 at Makassar strait. The data obtained was descriptively analyzed. The research result presented that the number of fish caught at shallow FAD 568 fish (45.92\%), consisted of skipjack tuna Katsuwonus pelamis (9.86\%), Bullet tuna Auxis rochei (8.65\%), Yellowfin Tuna Thunnus albacares (11.16\%) and Indian Mackerel Rastrelliger kanagurta (16.25\%). While 669 fish (54.08\%) caught at deep FAD consisted of Katsuwonus pelamis (11.80\%), and Rastrelliger kanagurta (18.35\%). The size spread of skipjack tuna (23-42 cm and 29-53 cm), Bullet Tuna $(16.5-25.0 \mathrm{~cm}$ and $18.5-28.5 \mathrm{~cm})$, Yellowfin Tuna (25$120 \mathrm{~cm}$ and $80-160 \mathrm{~cm})$ and Indian mackerel $(16-25 \mathrm{~cm}$ and 16-25 cm) for shallow and deep FAD respectively. The fish size distribution caught at shallow and deep FAD was skipjack tuna, whereas the Auxis rochei rochei and Thunnus albacares had bigger size distribution in deep sea FAD, while the Rastrelliger kanagurta had relatively similar size distribution in shallow or deep sea FAD.
\end{abstract}

Keywords: fish size, fish species composition, hand-line, shallow and deep sea FAD

\begin{abstract}
ABSTRAK
Penelitian ini bertujuan untuk menganalisis komposisi jenis dan ukuran ikan yang ditangkap pada rumpon laut dangkal dan rumpon laut dalam di Selat Makassar. Penelitian ini menggunakan metode survei dalam pengambilan data dan dilakukan selama 4 bulan mulai April-Juli 2016 di Selat Makassar. Data yang diperoleh dianalisis secara deskriptif. Hasil penelitian menunjukkan bahwa ikan yang ditangkap pada rumpon laut dangkal berjumlah 568 ekor $(45,92 \%)$, terdiri dari ikan cakalang $9,86 \%$, tongkol lisong $8,65 \%$, tuna madidihang $11,16 \%$ dan kembung lelaki $16,25 \%$. Ikan yang ditangkap pada rumpon laut dalam berjumlah 669 ekor $(54,08 \%)$, terdiri dari ikan cakalang $11,80 \%$, tongkol lisong $12,21 \%$, tuna madidihang $11,72 \%$ dan kembung lelaki $18,35 \%$. Sebaran ukuran ikan cakalang berkisar $23-42 \mathrm{~cm}$ dan $29-53 \mathrm{~cm}$, tongkol lisong $16,5-25,0 \mathrm{~cm}$ dan $18,5-28,5$ $\mathrm{cm}$, tuna madidihang berkisar $25-120 \mathrm{~cm}$ dan $80-160 \mathrm{~cm}$ serta ikan kembung lelaki berkisar $16-25$ $\mathrm{cm}$ dan $16-25 \mathrm{~cm}$ masing-masing untuk rumpon laut dangkal dan rumpon laut dalam. Distribusi ukuran ikan yang ditangkap pada rumpon laut dangkal dan rumpon dalam dari jenis ikan cakalang, ikan tongkol lisong dan tuna madidihang memiliki distribusi ukuran lebih besar pada rumpon laut dalam, sedangkan ikan kembung lelaki baik pada rumpon dangkal dan dalam memiliki distribusi ukuran relatif sama.
\end{abstract}

Kata kunci: ukuran ikan, komposisi jenis ikan, pancing ulur, rumpon dangkal dan dalam 


\section{PENDAHULUAN}

Wilayah Pengelolaan Perikanan Republik Indonesia (WPPRI 713) meliputi Selat Makassar, Teluk Bone, Laut Flores dan Laut Bali. Potensi perikanan pelagis besar di WPPRI 713 sebesar 419.342 ton, jumlah yang diperbolehkan untuk ditangkap sebesar 335.474 ton dengan tingkat pemanfaatan telah mencapai $0,86 \%$. Sementara itu, potensi perikanan pelagis kecil di WPPRI 713 sebesar 104.456 ton, jumlah yang diperbolehkan untuk ditangkap sebesar 83.637 ton dengan tingkat pemanfaatan telah mencapai 0,61\% (Kepmen KPRI Nomor 47 tahun 2016).

Perairan Selat Makassar merupakan salah satu daerah penangkapan ikan pelagis oleh nelayan dengan menggunakan alat tangkap pukat cincin, jaring insang hanyut, pancing ulur dan pancing tonda (Kantun et al. 2016). Nelayan pada umumnya melakukan operasi penangkapan dan menemukan gerombolan ikan menggunakan alat bantu rumpon. Penangkapan ikan pelagis dengan menggunakan alat bantu rumpon memberi dampak terhadap kelestarian sumberdaya ikan. Berdasarkan hasil kajian Western and Central Pacific Fisheries Commission (WCPFC 2009) mengungkapkan bahwa penggunaan seine net seperti pukat cincin dan payang yang dikombinasikan dengan rumpon memberikan tiga konsekuensi utama yang dapat berimplikasi kepada kelestarian sumberdaya ikan tuna/cakalang, yaitu meningkatnya kapasitas tangkap yang sulit dikontrol dan diukur, meningkatnya jumlah tangkapan ukuran juvenil ikan cakalang, meningkatnya hasil tangkapan sampingan seperti juvenil tuna mata besar dan tuna madidihang. Bromhead et al. (2003) dan WCPFC (2009) menjelaskan bahwa penggunaan alat bantu rumpon dalam penangkapan jenis ikan tuna/cakalang di Perairan Pasifik dapat meningkatkan jumlah ikan muda dibandingkan dengan penangkapan melalui pemburuan gerombolan ikan.

Beberapa penelitian yang telah dilakukan di Selat Makassar terkait penangkapan pada daerah rumpon antara lain dilakukan oleh Kantun et al. (2014) yang meneliti tentang perbandingan struktur ukuran tuna madidihang pada rumpon laut dalam berkisar $30-170 \mathrm{~cm}$ dengan bobot berkisar $0,30-73,80 \mathrm{~kg}$ dan rumpon laut dangkal berkisar $30-120 \mathrm{~cm}$, dengan bobot berkisar 0,3-33,40 kg; Kantun dan Faisal (2014) tentang hubungan bobot panjang tuna madidihang, Kantun (2016) tentang hasil tangkapan tongkol rochei memiliki distribusi ukuran 20,026,0 cm; Kantun dan Amir (2016) di perairan Teluk Bone memperoleh distribusi ikan tuna madidihang yang ditangkap dengan pancing ulur berkisar 40-160 cm, tongkol komo 10-62 $\mathrm{cm}$, tongkol krai $22-50 \mathrm{~cm}$, tongkol lisong 33-49 $\mathrm{cm}$, cakalang 43-58 cm dan tenggiri $85-140 \mathrm{~cm}$. Kantun et al. (2013) mendapatkan ikan pelagis yang ditangkap di perairan Selat Makassar pada daerah rumpon antara lain ikan kembung lelaki Rastrelliger kanagurta dan perempuan Rastrelliger brachysoma, tuna madidihang Thunnus albacares, tongkol lisong Auxis rochei, tongkol krai Auxis thazard, tongkol komo Euthynnus affinis, cakalang Katsuwonus pelamis, tenggiri Scomberomorus commersonii, tuna mata besar Thunnus obesus, ikan lemadang Coryphaena hippurus.

Berdasarkan beberapa hasil penelitian terdahulu memperlihatkan bahwa penelitian pada daerah rumpon sudah banyak dilakukan, namun belum ada satupun penelitian yang mengungkapkan tentang komposisi hasil tangkapan nelayan berdasarkan jenis ikan pada daerah rumpon di Selat Makassar. Penelitian ini bertujuan untuk mengamati tentang komposisi jenis ikan dan distribusi ukuran ikan pelagis yang ditangkap dengan menggunakan pancing ulur pada daerah rumpon.

\section{METODE}

Penelitian dilakukan dengan menggunakan metode survei dan terlibat langsung dalam proses penangkapan. Penangkapan menggunakan pancing ulur dengan spesifikasi terdiri dari tali utama, pemberat, swivel, tali pancing dan mata pancing. Tali utama terbuat dari bahan monofilamen berukuran 300-400 dan tali pancing juga dari bahan monofilamen berukuran 50-70. Pemberat terbuat dari timah dengan berat 250-350 gr serta ukuran mata pancing yang bervariasi tergantung target penangkapan. Penangkapan ikan tongkol dan ikan kembung menggunakan pancing nomor 10 dan 12 , sedangkan untuk menangkap ikan cakalang, tuna dan tongkol komo menggunakan pancing nomor 5 dan 7. Penangkapan ikan kembung dan tongkol dalam satu set pancing ulur dipasang 2 mata pancing dengan jarak 3-4 $\mathrm{m}$, sedangkan untuk menangkap ikan cakalang dan tuna, setiap satu pancing ulur hanya menggunakan 1 mata pancing dengan panjang tali pancing ulur adalah 30-75 m (Gambar 1).

Penelitian ini dilakukan selama 4 bulan mulai April sampai Juli 2016 dengan lokasi perairan Babana Kabupaten Mamuju Tengah Sulawesi Barat Selat Makassar (Gambar 2). Pengukuran sampel ikan dilakukan setiap minggu kedua dan keempat dalam setiap bulannya dengan pertimbangan keteraturan jedah pengamatan sampel dan kesiapan nelayan. Pengumpulan data dilakukan di tempat pendarat- 
an ikan Babana Budong-Budong dari kapal yang beroperasi di lokasi penelitian (15 titik posisi geografis lokasi penangkapan) (Gambar 2) dan tiga kali mengikuti nelayan untuk memastikan lokasi daerah penangkapan yang dijadikan lokasi penelitian.

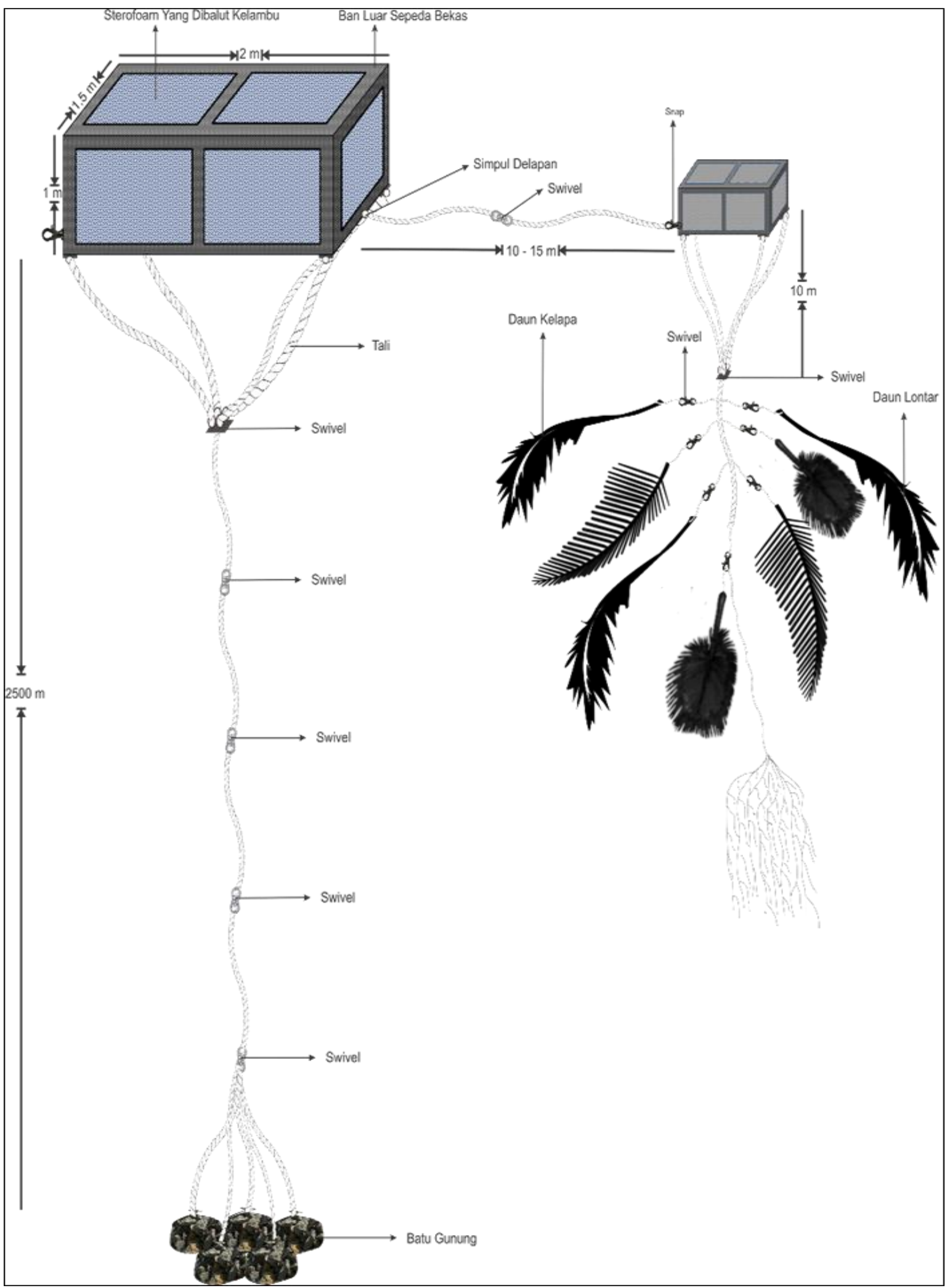

Gambar 1 Desain rumpon laut dangkal dan dalam, modelnya sama yang membedakan hanya panjang tali yang terhubung dengan pemberat 


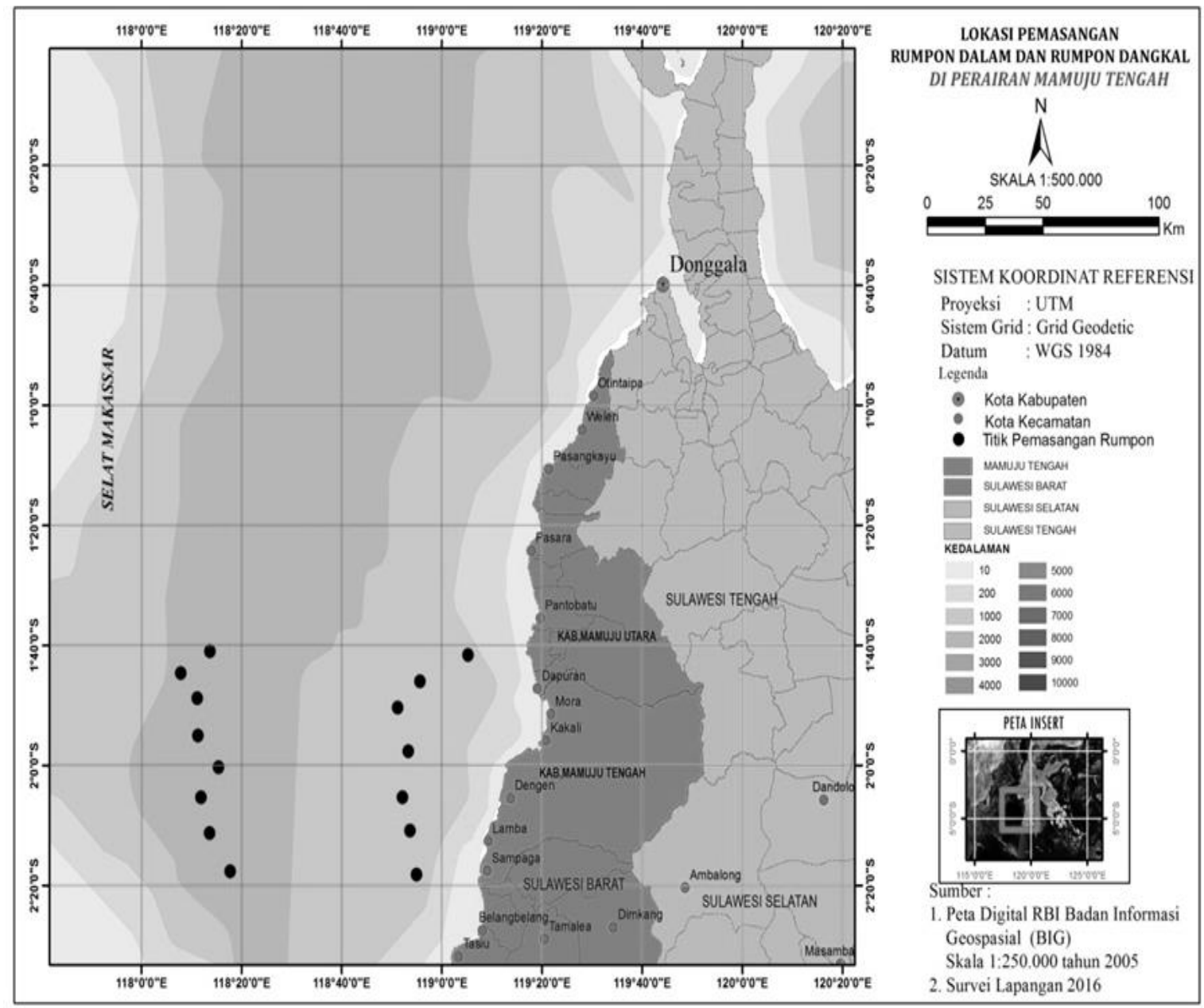

Gambar 2 Lokasi daerah penangkapan nelayan di Perairan Babana Selat Makassar

Lokasi daerah penangkapan adalah daerah rumpon laut dalam yang dipasang pada kedalaman di atas $200 \mathrm{~m}$ dan rumpon laut dangkal yang dipasang pada kedalaman kurang dari $200 \mathrm{~m}$

Daerah penangkapan merupakan rumpon yang sudah ada dan dipasang oleh nelayan sebelum penelitian dilakukan. Panjang ikan yang diukur pada penelitian ini adalah hasil tangkapan nelayan yang diukur panjang cagak dengan pertimbangan hasilnya lebih akurat dibanding menggunakan panjang total yang terkadang ekornya ada yang rusak. Pengukuran panjang dilakukan menggunakan meteran dengan ketelitian $0,1 \mathrm{~cm}$ terhadap semua hasil tangkapan nelayan yang menangkap pada daerah penelitian.

Bobot ikan (kondisi ikan belum disiangi) ditimbang dengan timbangan digital berketelitian 0,01 gr. Ikan ditimbang satu persatu dan dicatat dalam lembar kerja yang telah disiapkan. Ikan yang diukur adalah seluruh hasil tangkapan nelayan pada rumpon laut dalam dan dangkal. Ikan yang ditimbang dan diukur dipi- sahkan berdasarkan jenis ikan dan berdasarkan nelayan yang menangkap pada rumpon dalam dan dangkal.

Setelah diperoleh data distribusi panjang ikan yang tertangkap pada rumpon laut dangkal dan dalam dilanjutkan dengan menghitung proporsi setiap jenis ikan berdasarkan kelas ukuran. Data yang diperoleh kemudian ditabulasi untuk memisahkan komposisi hasil tangkapan (jenis, jumlah, dan ukuran panjang) berdasarkan jenis rumpon. Komposisi jumlah dan persentase setiap jenis hasil tangkapan dianalisis secara deskriptif, yang disajikan dalam bentuk Gambar. Komposisi jenis ikan yang ditangkapdi daerah rumpon dalam dan rumpon dangkal dihitung dengan formula menurut Odum (1971):

$$
\mathrm{H}=\frac{\mathrm{ni}}{\mathrm{N}} \text {. }
$$

dengan:

$\mathrm{H}$ : proporsi satu jenis ikan yang ditangkap pada rumpon

ni : jumlah jenis ikan ke-i

$\mathrm{N}$ : jumlah seluruh hasil tangkapan 


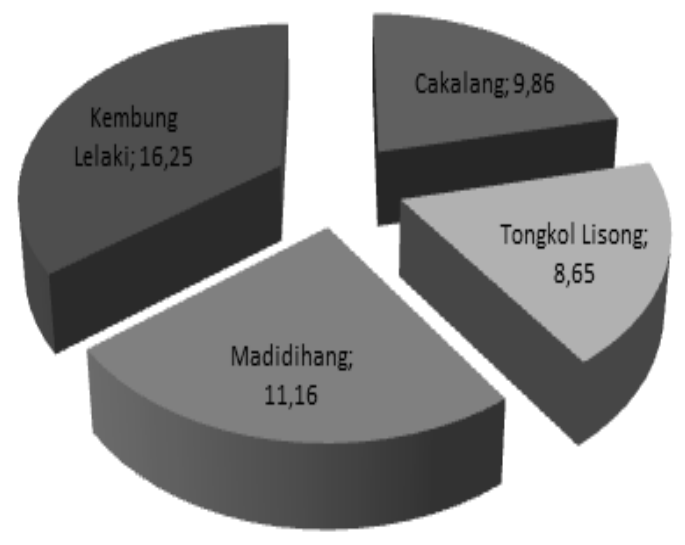

A

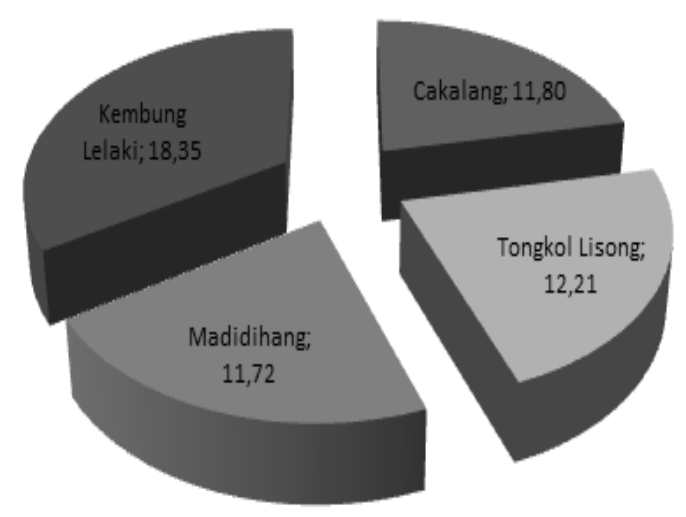

B

Gambar 3 Komposisi hasil tangkapan pada rumpon laut dangkal (A) dan dalam (B) periode AprilJuli 2016 di Selat Makassar

\section{HASIL DAN PEMBAHASAN}

\section{Komposisi Jenis Ikan}

Ikan sampel yang berhasil dikumpulkan selama penelitian berjumlah 1237 ekor yang terdiri dari 568 ekor ditangkap pada rumpon laut dangkal dan 669 ekor ditangkap pada rumpon laut dalam. Ikan sampel yang diperoleh selama penelitian terdiri dari jenis ikan cakalang Katsuwonus pelamis, tongkol lisong Auxis rochei, tuna madidihang Thunus albacares dan kembung lelaki Rastreliger kanagurta baik pada rumpon laut dangkal maupun rumpon laut dalam (Gambar 3).

Komposisi ikan tertinggi yang didapatkan pada rumpon laut dangkal adalah dari jenis ikan kembung sebesar 16,25\% dan terendah pada ikan tongkol lisong sebesar 8,65\% (Gambar $3 A$ ). Komposisi ikan tertinggi pada rumpon laut dalam dari jenis kembung lelaki sebesar $18,35 \%$ dan terendah ikan tuna madidihang sebesar 11,72\% (Gambar 3B). Kantun dan Amir (2016) di perairan Teluk Bone memperoleh komposisi hasil tangkapan pada daerah sekitar rumpon didominasi oleh tuna dan sejenisnya. Tuna madidihang Thunnus albacares sebanyak 494 ekor (46,69\%), tongkol komo Euthynus affinis sebesar 109 ekor (10,30\%), tongkol krai Auxis thazard sebesar 121 ekor $(11,44 \%)$, tongkol lisong Auxis rochei sebesar 137 ekor (12,95\%), ikan cakalang Katsuwonus pelamis sebesar 174 ekor $(16,45 \%)$ dan tenggiri Scomberomerus comersonii sebesar 23 ekor $(2,17 \%)$.

Pada penelitian ini hasil tangkapan dominan ditemukan pada ikan kembung lelaki baik pada rumpon laut dangkal maupun pada rumpon laut dalam. Hal ini disebabkan penangkapan ikan kembung dilakukan sepanjang hari, sementara ikan jenis lainnya hanya ditangkap pada waktu pagi dan sore hari sesuai dengan waktu makannya. Pada waktu ikan pelagis besar tidak mencari makan, maka kegiatan penangkapan tertuju pada ikan-ikan pelagis kecil. lkan kembung merupakan ikan pelagis kecil yang banyak ditangkap nelayan untuk konsumsi dan dipergunakan sebagai umpan untuk menangkap ikan pelagis besar. Ikan pelagis kecil merupakan target penangkapan alternatif ketika ikan pelagis besar berkurang. Hal senada diungkapkan oleh Kantun et al. (2014) bahwa ikan pelagis besar seperti tuna, tongkol dan cakalang memiliki waktu makan pada pagi dan sore hari. Hal ini terkait dengan kondisi suhu optimum lingkungan yang sesuai untuk melakukan aktifitas mencari makan.

Ada kecenderungan ikan-ikan yang ditangkap lebih banyak pada rumpon laut dalam diduga adalah ikan-ikan pelagis yang sebelumnya berada pada rumpon laut dangkal yang telah melakukan pergerakan ke rumpon laut dalam untuk mencari makanan atau untuk melakukan pemenuhan siklus hidupnya. Kantun (2016) menyatakan bahwa ikan-ikan pelagis akan melakukan migrasi horizontal menuju ke laut dangkal atau laut dalam dengan pertimbangan untuk melakukan reproduksi, mencari makanan, alasan keamanan, dan kenyaman dalam memenuhi siklus hidupnya.

Pada sisi lain, kemungkinan ini terkait dengan sifat biologinya yakni memiliki kebiasaan berkoordinasi dalam bergerombol. Ikan yang memiliki sifat biologi suka bergerombol akan memiliki sistem koordinasi yang baik. Sifat bergerombol memungkinkan ikan-ikan sejenis atau berbeda jenis dari ukuran yang sama akan membentuk gerombolan baru. Gerombolan ini akan membentuk komposisi jenis dan distribusi 
ukuran dalam gerombolan. Soria dan Dagorn (1992) berpendapat bahwa ikan yang bergerombol merupakan sekumpulan individu dengan ukuran, siklus biologi dan kemampuan biologi yang sama dalam suatu kelompok. Pada bagian lain, kemampuan ikan berkoordinasi ini merupakan ciri khas populasi ikan yang suka hidup bergerombol dan bergerak cepat secara bersamaan dan beriringan (Dewanti et al. 2014). Tingkah laku bergerombol dan suka bermigrasi ini juga akan berdampak pada berkurangnya sediaan sumberdaya pada suatu tempat tertentu dan melimpah pada tempat yang lain (Kantun 2016). Simbolon et al. (2011) berpendapat bahwa jenis hasil tangkapan ikan pada rumpon bisa berbeda berdasarkan lokasi dan waktu.

\section{Distribusi Ukuran}

Jenis-jenis ikan yang ditangkap pada rumpon laut dangkal dan dalam memiliki distribusi ukuran yang beragam berdasarkan jenis ikan. Ikan cakalang yang ditangkap pada daerah rumpon berjumlah 268 ekor yang terdiri dari 122 ekor ditangkap pada rumpon laut dangkal dan 146 ekor pada rumpon laut dalam. Ikan cakalang yang ditangkap pada rumpon laut dangkal memiliki distribusi ukuran berkisar $23-42 \mathrm{~cm}$ (rataan $27,31 \mathrm{~cm}$ ) dengan frekuensi dominan pada interval kelas $30-31 \mathrm{~cm}(9,84 \%)$, sedangkan pada rumpon laut dalam berkisar $29-53 \mathrm{~cm}$ (rataan $44,02 \mathrm{~cm}$ ) dan dominan pada interval kelas 39-40 cm (8,22\%) (Gambar 4).

Kantun dan Amir (2016) di Teluk Bone memperoleh distribusi ukuran Cakalang Katsuwonus pelamis berkisar $43-57 \mathrm{~cm}$ dan dominan pada ukuran $48-40 \mathrm{~cm}(12,07 \%)$.
Alamsyah et al. (2014) memperoleh distribusi ukuran ikan cakalang yang ditangkap di Teluk Bone berbeda pada masing-masing musim yakni pada musim peralihan pertama, musim timur, musim peralihan kedua, dan musim barat. Ukuran ikan yang ditangkap pada musim peralihan pertama memiliki panjang cagak berkisar antara 29,0-64,5 cm. Panjang ikan yang paling banyak ditangkap berkisar antara $44,8-48,7 \mathrm{~cm}$. Panjang rata-rata ikan adalah sebesar 46,74 $\pm 0,38 \mathrm{~cm}$. Distribusi ukuran pada musim timur berkisar antara 29,0-64,5 cm dan panjang ikan yang paling banyak ditangkap pada kisaran 44,8-48,7 cm. Perbedaan distribusi ukuran pada setiap musim disebabkan pada musim barat distribusi ukuran ikan berukuran lebih kecil dibandingkan tiga musim lainnya disebabkan karena aktivitas penangkapan oleh Pole and Line hanya dilakukan didaerah pantai dengan jumlah armada yang terbatas. Sementara pada musim peralihan II distribusi ukuran ikan bervariasi mulai dari ukuran kecil sampai ukuran besar. Variasi distribusi ukuran ini karena tingginya aktivitas penangkapan ikan cakalang di Teluk Bone dimana pada musim peralihan II ini yang merupakan musim terbaik untuk menangkap ikan.

Distribusi ukuran ikan cakalang yang ditangkap dengan purse seine di perairan Laut Flores bagian Timur pada kisaran panjang cagak 19,5-59,5 cm, ukuran panjang rata-rata individu $41,9 \mathrm{~cm}$ dan ukuran panjang dominan berada pada kisaran panjang 19,5-24,5 cm dan $45,5-49,5 \mathrm{~cm}$. Distribusi ukuran ikan cakalang yang ditangkap oleh nelayan menggunakan purse seine di perairan Laut Flores bagian Barat memiliki kisaran panjang cagak 19,5-69,5 $\mathrm{cm}$ dengan panjang rata-rata individu $34,6 \mathrm{~cm}$, -

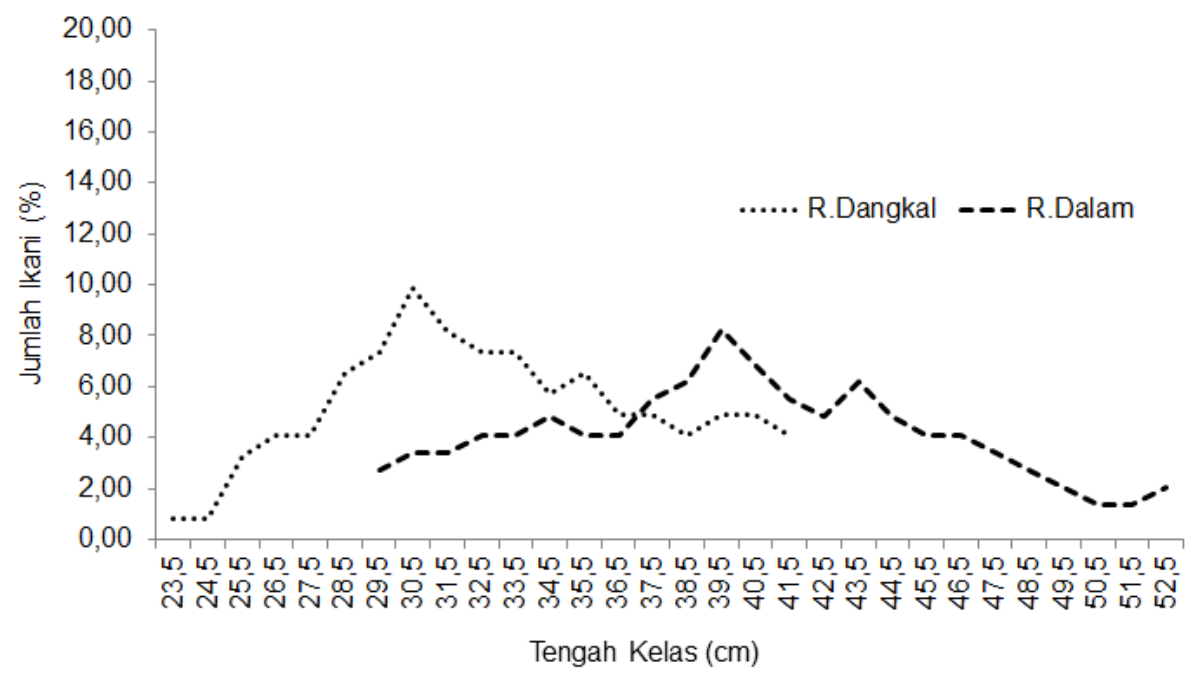

Gambar 4 Distribusi ukuran ikan cakalang pada rumpon dangkal dan dalam periode April-Juli 2016 di Selat Makassar 


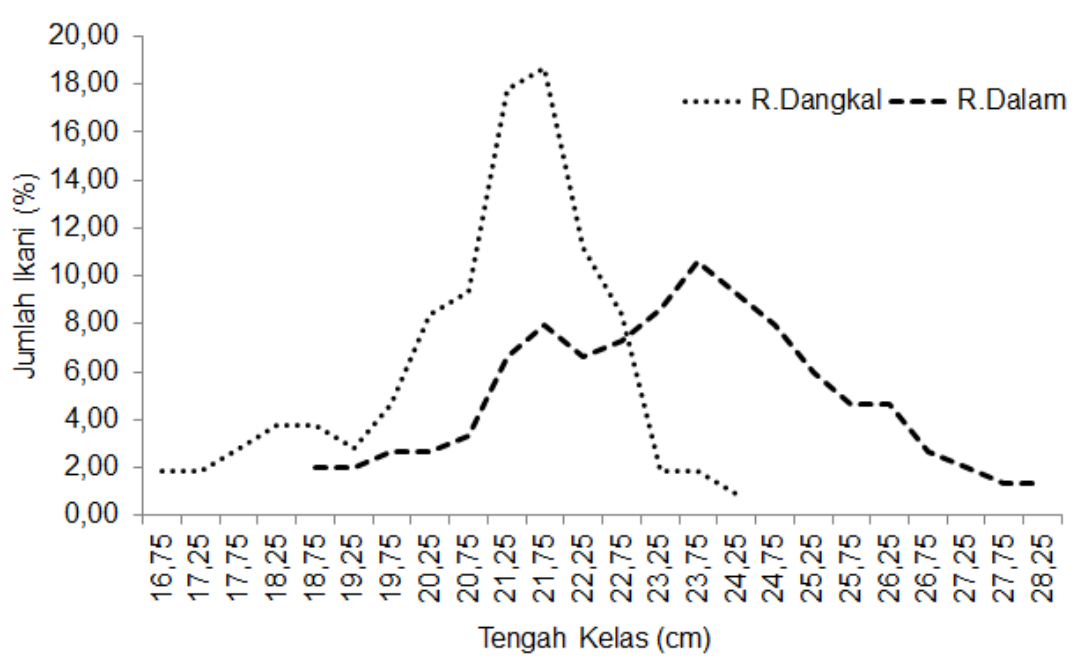

Gambar 5 Distribusi ukuran ikan tongkol Auxis rochei pada rumpon dangkal dan dalam periode April-Juli 2016 di Selat Makassar

dan ukuran dominan berada pada kisaran panjang 24,5-34,5 cm (Mallawa et al. 2014). Ma yer dan Andrade (2008) di barat daya Samudera Atlantik mendapatkan ukuran ikan cakalang berkisar $32-80 \mathrm{~cm}$.

Distribusi ukuran ikan cakalang pada penelitian ini memiliki kecenderungan ukuran lebih besar ditangkap pada rumpon laut dalam. Hal ini diduga disebabkan oleh metode penangkapan terkait dengan kedalaman tali pancing, jenis umpan dan waktu penangkapan. Panjang tali pancing menentukan kedalaman tali pancing dioperasikan dan berhubungan dengan kemampuan menjangkau daerah renang ikan cakalang. Sementara itu, jenis umpan yang dipergunakan berhubungan dengan kebiasaan makan ikan cakalang dan waktu penangkapan berkaitan dengan waktu makan ikan cakalang. Selain itu, sifat biologi ikan cakalang yang aktif mencari makan pada pagi dan sore hari kemungkinan turut berperan dalam menentukan distribusi ukuran ikan cakalang yang tertangkap. Kantun et al. (2014) berpendapat bahwa metode penangkapan yang berhubungan dengan perbedaan waktu penangkapan, waktu makan ikan, jenis umpan, dan posisi kedalaman pengoperasian pancing berkontribusi terhadap ukuran ikan yang tertangkap.

Ikan tongkol lisong yang ditangkap pada daerah rumpon berjumlah 258 ekor yang terdiri dari 107 ekor ditangkap pada rumpon laut dangkal dan 151 ekor pada rumpon laut dalam. Ikan tongkol lisong yang ditangkap pada rumpon laut dangkal memiliki distribusi ukuran berkisar 16,5-25,0 cm dengan frekuensi dominan pada interval kelas $22,0-22,5 \mathrm{~cm}(18,69 \%)$, sedangkan pada rumpon laut dalam berkisar $18,5-28,5 \mathrm{~cm}$ dan dominan pada interval kelas $24,0-24,5 \mathrm{~cm}(18,69 \%)$ (Gambar 5).
Kantun dan Amir (2016) di Teluk Bone memperoleh distribusi ukuran tongkol lisong Auxis rochei pada panjang cagak berkisar 33$49 \mathrm{~cm}$, dominan pada ukuran 41-42 (14,60\%), tongkol komo Euthynus affinis yang ditangkap pada panjang cagak $10-62 \mathrm{~cm}$, dominan pada ukuran 50-52 (9,17\%), tongkol krai Auxis thazard pada kisaran $22-50 \mathrm{~cm}$, dominan pada ukuran 22-50 (7,44\%). Kantun et al. (2016) di perairan Babana Mamuju Tengah memperoleh distribusi ukuran ikan tongkol lisong berkisar $15,5-28,5 \mathrm{~cm}$, dengan distribusi ukuran tongkol lisong betina berkisar $15,5-28,5 \mathrm{~cm}$, dominan pada interval kelas $24,0-24,5 \mathrm{~cm}$ sebesar $14,36 \%$ (175 ekor), sedangkan tongkol lisong jantan berkisar 17,0-28,0 cm, dominan pada interval kelas $24,0-24,5 \mathrm{~cm}$ sebesar $14,60 \%$ (135 ekor). Kahraman et al. (2010) dengan menggunakan pukat cincin dan pancing tonda di pantai Turki Mediterranean memperoleh pada ukuran berkisar $34-48 \mathrm{~cm}$. Sementara itu, Macias et al. (2006) diperoleh sebaran ukuran tongkol lisong di sebelah Tenggara Mediterranean pada panjang cagak berkisar $25-47 \mathrm{~cm}$. Tongkol lisong yang tertangkap di perairan Selat Gibraltar pada panjang cagak $47 \mathrm{~cm}$ dengan bobot $1,9 \mathrm{~kg}$ (Rodiguez-roda 1966). Macias et al. (2005) di barat daya Mediteranian Spanyol mendapatkan pada kisaran 33,4-47 cm serta Bok dan Oray (2001) di perairan Turky mendapatkan pada kisaran $28,5-44,5 \mathrm{~cm}$.

Distribusi ukuran ikan tongkol lisong yang diperoleh pada penelitian ini lebih kecil dibanding peneliti-peneliti terdahulu. Hal ini kemungkinan berkaitan dengan aktifitas penangkapan, musim penangkapan, daya dukung lingkungan. Aktivitas penangkapan berkaitan dengan jumlah alat tangkap dan jenis alat tangkap yang dipergunakan sehingga dapat menyebabkan 
tekanan penangkapan. Musim penangkapan yang terkait dengan waktu pengamatan sampel dilakukan terhadap ikan tongkol lisong tidak sama dan daya dukung lingkungan yang berhubungan dengan kondisi lingkungan dan ketersediaan makanan kemungkinan berkontribusi terhadap preferensi sebaran distribusi ukuran. Jasmine et al. (2013) berpendapat bahwa tongkol lisong tergolong ikan yang tidak selektif dalam mencari makanan. Sifat ini dapat menyebabkan ketersediaan makanan cepat mengalami penurunan. Penurunan tersebut di duga dapat menyebabkan pergerakan ikan tongkol untuk berpindah ke tempat lain. Pergerakan tersebut dapat menjadi indikator perubahan komposisi dan distribusi ukuran ikan pada suatu daerah tertentu.

Tuna madidhang yang diperoleh selama penelitian berjumlah 283 ekor yang terdiri dari 138 ditangkap di rumpon laut dangkal dan 145 pada rumpon laut dalam. Distribusi ukuran yang ditangkap pada rumpon laut dangkal berkisar $25-120 \mathrm{~cm}$ dan tertinggi pada kelas 7075 dengan frekuensi 10,14\% (914 ekor) dan terendah pada kelas $25-30 \mathrm{~cm}$ sebesar $1,45 \%$ (2 ekor). Sementara itu, yang ditangkap pada rumpon laut dalam berkisar $80-160 \mathrm{~cm}$ dengan frekuensi tertinggi diperoleh pada kelas 120$125 \mathrm{~cm}$ sebesar $11,72 \%$ (17 ekor) dan terendah pada kelas $80-85 \%$ sebesar $2,07 \%$ (3 ekor) (Gambar 6).

Coasta et al. (2005) di pantai Timur Laut Brasil mendapatkan ikan tuna madidihang yang tertangkap dengan longline pada ukuran berkisar $80-150 \mathrm{~cm}$, sedangkan Mayer dan Andrade (2008) di barat daya Samudera Atlantik mendapatkan ukuran berkisar 41-121 cm. Kantun et al. (2013) memperoleh distribusi ukuran berki- sar $25-180 \mathrm{~cm}$, dengan rincian yang ditangkap pada pagi hari ukuran panjang cagaknya berkisar 25-130 cm, ukuran dominan ditangkap pada kelas $100-105 \mathrm{~cm}$ dengan panjang rataan $95,4 \pm 3,90 \mathrm{~cm}$.

Sementara itu, tuna madidihang yang ditangkap pada sore hari berkisar $25-180 \mathrm{~cm}$ dengan ukuran dominan ditangkap pada tengah kelas 110-115 cm dan panjang rataan 113,50 \pm $3,80 \mathrm{~cm}$. Kantun dan Amir (2016) di perairan Teluk Bone memperoleh distribusi ukuran tuna madidihang yang ditangkap pada kisaran panjang cagak 40-160 cm, dominan pada ukuran 65-70 cm (7,66\%). Kantun et al. (2014) di Selat Makassar memperoleh distribusi ukuran tuna madidihang yang ditangkap pada rumpon laut dangkal berkisar $30-120 \mathrm{~cm}$, rataan 64,64 \pm 2,26 cm dengan bobot berkisar 0,4-35 kg dan rumpon laut dalam berkisar $105-170 \mathrm{~cm}$ dengan rataan $134,90 \pm 1,90 \mathrm{~cm}$ dengan bobot berkisar $20-75 \mathrm{~kg}$. Kantun dan Mallawa (2015) memperoleh distribusi ukuran tuna madidihang yang ditangkap pada pagi hari berkisar 25-130 $\mathrm{cm}$, dominan pada ukuran 100-105 cm dan sore hari berkisar $25-180 \mathrm{~cm}$ dengan ukuran dominan pada kisaran 110-115 cm. Sebaran ukuran yang diperoleh pada penelitian ini tidak berbeda jauh dengan hasil-hasil penelitian yang dilakukan oleh peneliti terdahulu. Hal ini terjadi karena waktu penelitian merupakan musim penangkapan tuna, metode penangkapan yang digunakan mampu menjangkau daerah renang tuna madidihang, kemampuan mengenali sifat biologi ikan tuna terkait dengan waktu makan dan jenis umpan yang disukai.

Ikan kembung lelaki yang diperoleh selama penelitian berjumlah 428 ekor dengan distribusi ukuran pada rumpon laut dangkal dan

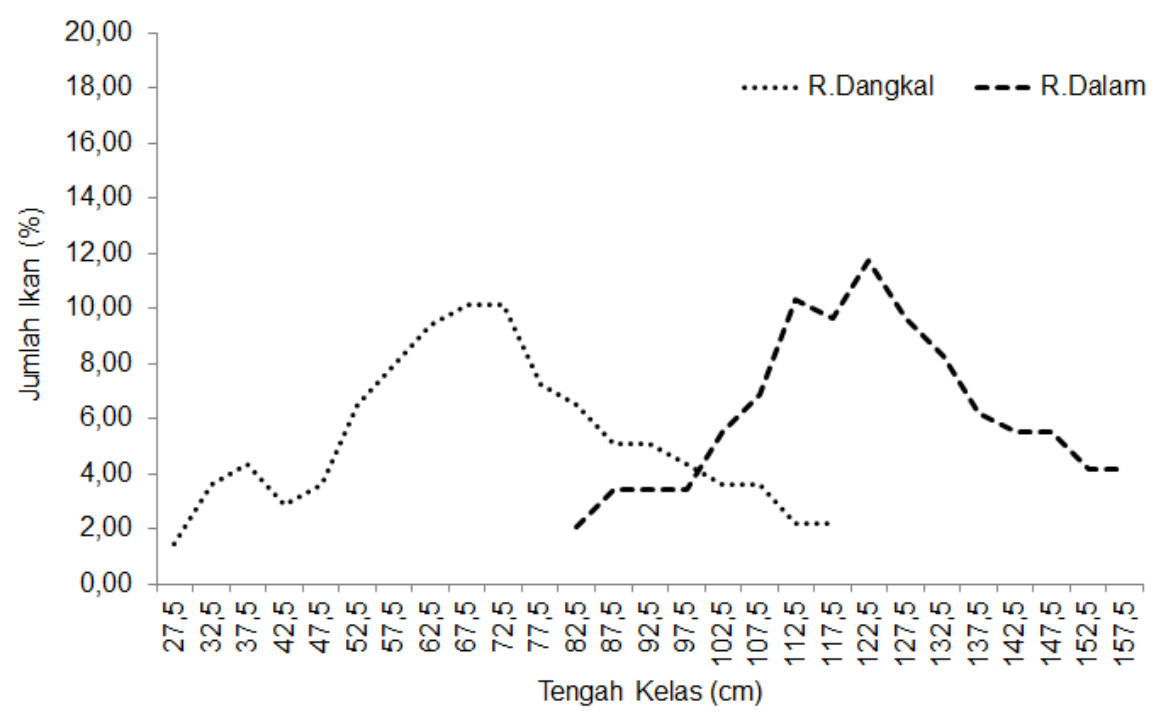

Gambar 6 Distribusi ukuran tuna madidihang Thunnus albacares pada rumpon dangkal dan dalam periode April-Juli 2016 di Selat Makassar. 


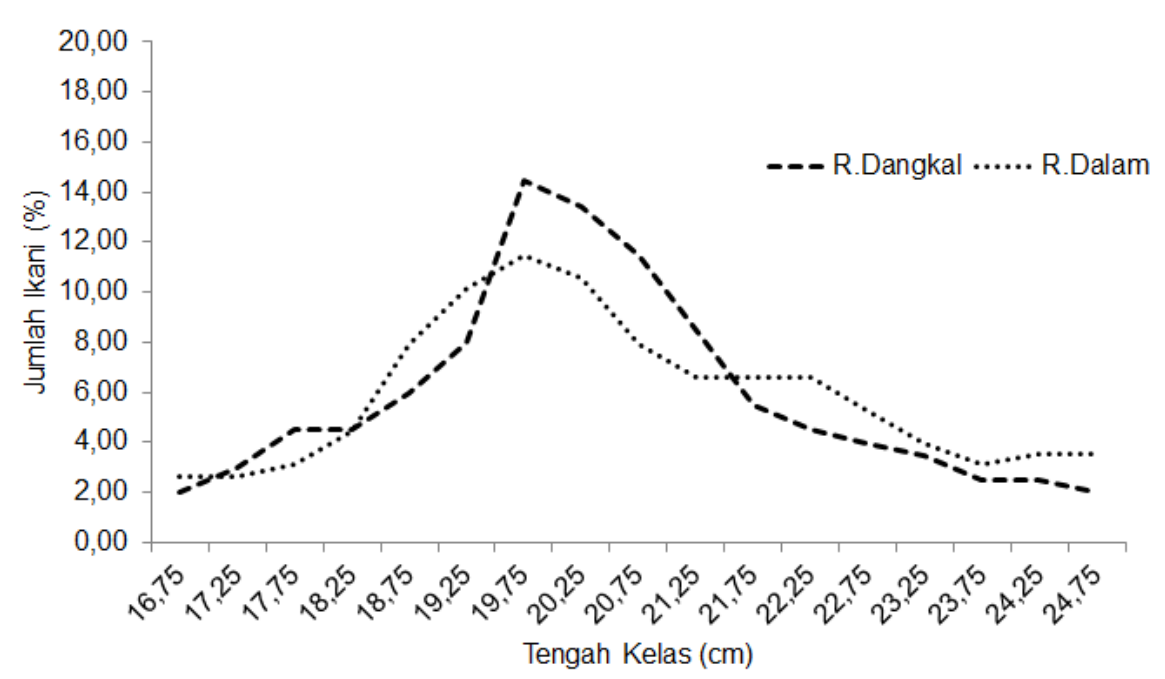

Gambar 7 Distribusi ukuran kembung lelaki Rastrelliger kanagurta pada rumpon dangkal dan dalam periode April-Juli 2016 di Selat Makassar

dalam berkisar $16-25 \mathrm{~cm}$ dan dominan pada kelas $19,5-20,0 \mathrm{~cm}$ sebesar $14,43 \%$ (29 ekor) untuk rumpon laut dangkal dan sebesar $11,45 \%$ (26 ekor) pada rumpon laut dalam (Gambar 7). Kasmi et al. (2017) di perairan pesisir Takalar dan Makassar memperoleh sampel berjumlah 2103 ekor yang terdiri atas 934 ekor dari pesisir Takalar dan 1169 ekor sampel dari pesisir Makassar yang ditangkap dengan menggunakan alat tangkap pancing ulur pada daerah rumpon. Sampel dari daerah penelitian pesisir Takalar terdiri dari 405 ekor jenis kelamin betina dan 529 ikan jantan dengan ukuran panjang dan bobot berkisar 13,3-25,3 cm dan 35,13-203,06 gram. Sementara ikan jantan berukuran panjang dan bobot berkisar 13,1$24,5 \mathrm{~cm}$ dan 37,82-216,75 gram. Sampel dari pesisir Makassar terdiri dari 597 ekor jenis kelamin betina dan 572 ikan jantan. Ukuran panjang dan bobot ikan betina berkisar 13,3$24,7 \mathrm{~cm}$ dan 38,78-202,16 gram. Sementara itu, ikan jantan berukuran panjang dan bobot berkisar berkisar $13,0-24,8 \mathrm{~cm}$ dan 35,10 203,06 gram.

Setiap peneliti mendapatkan distribusi ukuran ikan yang berbeda-beda dengan menggunakan alat tangkap pancing. Perbedaan tersebut diduga terkait dengan perbedaan fisik dari setiap ukuran mata pancing. Erzini et al. (1998) berpendapat bahwa jumlah dan komposisi jenis hasil tangkapan pada perikanan pancing dapat dipengaruhi oleh dua faktor penting yaitu tipe dan ukuran mata pancing. Sementara itu, Rahmat (2007) mengatakan bahwa perbedaan fisik dari tiap ukuran mata pancing dapat mempengaruhi bobot maupun jumlah tiap jenis tangkapan pada perikanan pancing. Ukuran mata pancing dapat mempengaruhi komposisi ukuran ikan yang tertangkap dari segi bobot dan panjang. Pada sisi lain sifat biologi ikan, karakteristik daerah penangkapan dan metode penangkapan diduga turut berperan dalam menentukan komposisi dan distribusi ukuran.

Oktaviani et al. (2014) mendapatkan distribusi ukuran ikan kembung lelaki pada panjang cagak berkisar 6,3-26,0 cm. Distribusi ukuran yang berbeda pada setiap peneliti disebabkan selektivitas alat tangkap, metode penangkapan. dan sifat biologi ikan. Selektivitas terkait dengan ukuran mata pancing yang dipergunakan, metode penangkapan berhubungan dengan waktu penangkapan, jenis umpan, panjang tali pancing terkait dengan kedalaman renang ikan. Sementara itu, sifat biologi dimaksud seperti tingkah laku bergerombol ikan, yang pada umumnya akan bergerombol dengan ukuran yang sama dengan jenis yang sama. Jika diperoleh distribusi ukuran yang berbeda-beda kemungkinan secara biologi terdiri dari beberapa kelompok umur dan ukuran. Ikan yang bergerombol merupakan sekumpulan individu dengan ukuran dan siklus biologi yang sama (Kasmi et al. 2017). Dewanti et al. (2014) berpendapat bahwa populasi ikan dewasa merupakan ikan yang suka hidup bergerombol dan bergerak cepat secara bersamaan dan beriringan.

\section{KESIMPULAN}

Jenis hasil tangkapan yang diperoleh pada rumpon laut dangkal dan dalam adalah sama yakni ikan cakalang (Katsuwonus pelamis), ikan tongkol lisong (Auxis rochei), Madidihang (Thunnus albacares) dan ikan kembung 
lelaki (Rastrelliger kanagurta). Sementara komposisi jenis hasil tangkapan dominan pada rumpon laut dangkal dan dalam adalah ikan kembung lelaki (Rastrelliger kanagurta). Distribusi ukuran ikan yang ditangkap pada rumpon laut dangkal dan rumpon dalam dari jenis ikan cakalang, ikan tongkol lisong dan tuna madidihang memiliki distribusi ukuran lebih besar pada rumpon laut dalam, sedangkan ikan kembung lelaki baik pada rumpon dangkal dan dalam memiliki distribusi ukuran relatif sama.

\section{SARAN}

Keberlanjutan sumberdaya ikan cakalang (Katsuwonus pelamis), ikan tongkol lisong (Auxis rochei) dan tuna Madidihang (Thunnus albacares) dapat dijaga dengan menangkap pada rumpon laut dalam.

\section{UCAPAN TERIMA KASIH}

Ucapan terima kasih disampaikan kepada Kementistekdikti atas bantuan pendanaan penelitian PSNI, kepada koperasi usaha bersama atas keterlibatan nelayan plasmanya dalam penelitian ini, dan kepada Dinas Perikanan dan Kelautan Mamuju Tengah serta terima kasih kepada seluruh tim peneliti.

\section{DAFTAR PUSTAKA}

Alamsyah R, Musbir, Amir F. 2014. Struktur Ukuran dan Ukuran Layak Tangkap Ikan Cakalang Katsuwonus pelamis di Perairan Teluk Bone. Jurnal Ipteks Pemanfaatan Sumberdaya Perikanan. 2(1): 11-20.

Bök T, Oray IK. 2001. Age and Growth of Bullet Tuna Auxis Rochei (Risso, 1810) in Turkish Waters. ICCAT, Columbia. Volume. Science. Paper. 52: 708-718.

Bromhead D, Foster J, Attard R, Findlay J, Kalish J. 2003. A Review of the Impact of Fish Aggregating Devices (FADs) on Tuna Fisheries. Final Report to the Fisheries Resources. 121 p.

Costa FES, Braga FMS, Amorim AF, Arfelli CA. 2005. Fishery Biology of the Yellow-Fin Tuna, Thunnus albacares, in the Southern Brazil. Col. Volume Science Paper. ICCAT. 58(1): 309-349.

Dewanti RON, Ghofar A, Saputra SW. 2014. Beberapa Aspek Biologi Ikan Teri (Stolephorus devisi) yang Ditangkap
Payang di Perairan Kabupaten Pemalang. Diponegoro Journal of Maquares. 3(4): 102-111.

Erzini K, Goncalves JMS, Bentes L, Lino PG, Ribeiro J. 1998. Species and Size Selectivity in a 'Red' Sea Bream Longline 'Metier' in the Algarve (Southern Portugal). Aquatic Living Resources. 11(1): 1-11.

Jasmine $S$, Prathibha R, Abdussamad EM, Said KPK, Joshi KK, Kemparaju S, Prakasan D, Elayathu MNK, Manju S. 2013. Biology and Fishery of the Bullet Tuna, Auxis rochei (Risso, 1810) in Indian Waters. Indian J. Fish. 60(2): 1320.

Kahraman AE, Didem G, Erol RB, Tulay A, Saadet K. 2010. Some Reproductive Aspects of Female Bullet Tuna, Auxis rochei (Risso), from the Turkish Mediterranean Coasts. African Journal of Biotechnology. 9(40): 6813-6818.

Kantun W, Mallawa A, Rapi NL. 2013. Kajian Optimalisasi Pemanfaatan Tuna di Selat Makassar. Penelitian $\mathrm{MP}_{3} \mathrm{El}$ Tahun Pertama. Ditjen Dikti Penelitian dan Pengabdian pada Masyarakat.

Kantun W, Mallawa A, Rapi NL. 2014. Perbandingan Struktur Ukuran Tuna Madidihang Thunnus albacares yang Ditangkap pada Rumpon Laut Dalam dan Laut Dangkal di Perairan Selat Makassar. Jurnal IPTEKS Pemanfaatan Sumberdaya Perikanan. 1(2): 112-128.

Kantun W, Faisal A. 2014. Hubungan Bobot Panjang Tuna Madidihang Thunnus albacares dari Perairan Majene Selat Makasar. Jurnal Balik Diwa. 4(1): 1-7.

Kantun W dan Mallawa A. 2015. Respon Tuna Madidihang Thunnus albacares terhadap Umpan dan Kedalaman pada Perikanan Handline di Selat Makassar. Journal of Fisheries Science. 17(1): 1-9.

Kantun W. 2016. Hasil Tangkapan dan Struktur Ukuran Ikan Tongkol Lisong Auxis rochei Berdasarkan Jenis Umpan, Kedalaman dan Waktu Penangkapan pada Perikanan Pancing Ulur di Majene Selat Makassar. Disajikan pada Seminar Nasional Perikanan XIII Universitas Gadjah Mada. 13 Agustus 2016.

Kantun W dan Amir MF. 2016. Aspek Biologi dan Komposisi Hasil Tangkapan Pancing Ulur di Teluk Bone. Jurnal Balik Diwa. 7(1): 1-12. 
Kantun W, Cahyono I, Arsana WS. 2016. Pemanfaatan Sumberdaya Ikan Tongkol Melalui Pendekatan Terpadu untuk Meningkatkan Produktifitas Nelayan di WPPRI 713. Laporan Penelitian $\mathrm{MP}_{3} \mathrm{El}$ Tahun Pertama.

Kasmi M, Syamsul H, Kantun W. 2017. Biologi Reproduksi Ikan Kembung Lelaki Rastrelliger kanagurta (Cuvier, 1816) di Pesisir Takalar. Jurnal Iktiologi Indonesia. 17 (3): 132-152.

Kepmen KPRI, Nomor 47/KEPMEN-KP. 2016. Estimasi Potensi, Jumlah Tangkapan yang Diperbolehkan, dan Tingkat $\mathrm{Pe}$ manfaatan Sumber Daya Ikan di Wilayah Pengelolaan Perikanan negara Republik Indonesia. 6 hal.

Macias D, Gòmez-Vives MJ, De la Serna JM. 2005. Some Reproductive Aspects of Bullet Tuna (Auxis rochei) from the South Western Spanish Mediterranean. ICCAT, Columbia. Volume. Science. Paper. 58(2): 484-495.

Macías D, Lema L, Gomez-Vives MJ, Ortiz de Urbina JM, de la Serna JM. 2006. Some Biological Aspects of Small Tunas (Euthynnus alletteratus, Sarda sarda, \& Auxis rochei) from the South Western Spanish Mediterranean. ICCAT, Colum bia. Volume. Science. Paper. 59(2): 579589.

Mallawa A, Faisal A, Mukti Z. 2014. Keragaan Biologi Populasi Ikan Cakalang (Katsuwonus pelamis) yang Ditangkap dengan Purse Seine pada Musim Timur di Perairan Laut Flores. Jurnal IPTEKS Pemanfaatan Sumberdaya Perikanan. 1(2): 129-145.
Mayer FP, Andrade HA. 2008. Size of Yellowfin Tuna (Thunnus albacares) Caught by Pole and Line Fleet in the Southwestern Atlantic Ocean. Brazilia Journal Aquatic Science Technology. 12(1): 59-62.

Odum EP. 1971. Fundamentals of Ecology. H B/Holt/Saunders. Philadelphia. P.574

Oktaviani D, Supriatna J, Erdmann MV, Abinawanto. 2014. Maturity Stage of Indian Mackerel Rastreliger kanagurta (Cuvier, 1816) in Mayalibit Bay, Raja Ampat, West Papua. International Journal of Aquatic Science. 5(1): 67-76.

Rahmat E. 2007. Penggunaan Pancing Ulur (Hand Line) untuk Menangkap Ikan Pelagis Besar di Perairan Bacan, Halmahera Selatan. Jurnal Penelitian Perikanan Laut, 6(1): 29-33.

Rodríguez RJ. 1966. Estudio De La Bacoreta, Euthynnus alletteratus (Raf.), Bonito, Sarda sarda (Bloch) melva Auxis thazard (Lac.), Capturados Por Las Almadrabas Españolas. Invest. Pesq. 30: 247.

Soria M, Dagom L. 1992. Rappels Surle Comportement Grégaire. in: Action Incitative Comportement Agrégatif (AICA),Compte-Rendu de Réunion, Doc. Centre ORSTOM Montpellier. 9: 5-9.

Simbolon D, Jeujanan B, Wiyono ES. 2011. Efektifitas Pemanfaatan Rumpon pada Operasi Penangkapan Ikan di Perairan Kei Kecil, Maluku Tenggara. Jurnal Marine Fisheries. 2(1): 19-28.

WCPFC. 2009. Summary Report-Scientific Committee Fifth Regular Session. Port Vila Vanuatu. 29 p. 